\title{
Analisis Perilaku Pelaku Bullying dan Upaya Penanganannya (Studi Kasus Pada Siswa MAN 1 Barru)
}

\author{
Mujtahidah \\ Madrasah Aliyah 1 Barru, Indonesia \\ e-mail: mujtahidahida@gmail.com
}

\begin{abstract}
Abstrak
Tujuan penelitian ini untuk mengetahui (i) Gambaran perilaku bullying yang meliputi: bentuk - bentuk perilaku bullying, dan karakteristik pelaku, (ii) Faktor penyebab terjadinya bullying, (iii) Dampak perilaku bullying, dan (iv) Upaya penanganan yang telah dilakukan guru BK. Penelitian ini menggunakan pendekatan kualitatif dengan jenis penelitian studi kasus dengan teknik pengumpulan data melalui wawancara mendalam (indepth interview), observasi dan dokumentasi. Data yang diperoleh dianalisis dengan analisis deskripftif kualitatif dan teknik analisis data yang digunakan adalah reduksi data, display data, dan penarikan kesimpulan. Hasil penelitian ini menunjukkan bahwa: (i) gambaran perilaku pelaku bullying, meliputi bentuk bullying fisik: memukul, meninju, menendang, menampar, mendorong dan memalak; bentuk bullying verbal: memarahi, menghina, mengejek dan memanggil dengan sebutan yag buruk. Adapun karakteristik pelaku: kurang empati, mudah marah, dan impulsif. (ii) faktor yang mempengaruhi perilaku bullying adalah: (a) pengalaman masa kecil (b) kurang perhatian dari orang tua, (c) dukungan dari teman sebaya, (d) faktor kepribadian pelaku. (iii) dampak perilaku bullying bagi kasus ZA adalah hubungan sosial dengan teman sekelas yang tidak baik karena ZA dijauhi akibat perilakunya. (iv) bentuk penanganan perilaku bullying yang telah dilakukan oleh guru BK adalah teknik konseling yang lebih pada pemberian nasehat.
\end{abstract}

Kata Kunci: bullying, agresif, intimidasi, kepribadian. lingkungan dan perilaku.

\section{PENDAHULUAN}

Kenakalan remaja di tingkat sekolah menengah sudah menjadi bagian fenomena umum yang memperihatinkan. Mujiati (2015:1) mengemukakan "salah satu masalah yang berkembang di sekolah adalah kecenderungan siswa melakukan perilaku bullying. Perilaku bullying telah lama menjadi bagian dari dinamika yang ada di sekolah." Kasus bullying di sekolah hendaknya menjadi perhatian bagi pengelola pendidikan untuk segera mengatasi kasus bullying di sekolah. Sebagaimana yang termuat dalam UUD 1945 pasal 28B (ayat 2): "Setiap anak berhak atas kelangsungan hidup, tumbuh dan berkembang, serta berhak atas perlindungan dari kekerasan dan diskriminasi".

Undang-Undang Perlindungan Anak No.23 Tahun 2002 Pasal 54 juga memuat bahwa: "Anak di dalam dan di lingkungan sekolah wajib dilindungi dari tindakan kekerasan yang dilakukan oleh guru, pengelola sekolah, atau temantemannya di dalam sekolah yang bersangkutan, atau lembaga pendidikan lainnya".

Rigby (2002), menyatakan bahwa sekolah menjadi titik awal terjadinya bullying dan tidak diragukan lagi bahwa intimidasi terjadi di sekolah dan menyebabkan beberapa anak menderita, ketidak pedulian teman-teman, minimnya pengawasan dari sekolah, dan kurangnya perhatian orang tua menjadi dugaan alasan meluasnya kecenderungan perilaku bullying.

Bullying merupakan sebuah kata serapan dari bahasa Inggris. Bullying berasal dari kata bully yang artinya penggertak, atau orang yang mengganggu orang yang lemah. Secara psikologis, bullying adalah ekspresi muka yang merendahkan, kasar atau tidak sopan, mempermalukan dan mengucilkan. American Psychological Association (2013) mengartikan bullying sebagai: "A form of aggressive behavior in which someone intentionally and repeatedly causes another person injury or discomfort. Bullying can take the form of physical contact, words or more subtle actions".

Menurut Susanti (2006), beberapa istilah dalam bahasa Indonesia yang seringkali dipakai untuk menggambarkan fenomena bullying di antaranya adalah penindasan, penggencetan, perpeloncoan, pemalakan, pengucilan, atau intimidasi. Sedangkan menurut Coloroso (2003) bahwa bullying adalah tindakan bermusuhan yang dilakukan secara sadar dan disengaja yang bertujuan untuk menyakiti seperti menakuti melalui ancaman agresi dan menimbulkan teror termasuk tindakan yang direncanakan maupun secara spontan, bersifat nyata atau hampir tidak terlihat dihadapan seseorang atau 
dibelakang seseorang, mudah untuk diidentifikasi atau terselubung dibalik persahabatan, dilakukan oleh seseorang atau sekelompok anak.

Wiyani (2012) mengemukakan pendapat Dan Olweus bahwa bullying mengandung tiga unsur mendasar dari perilaku pelaku bullying sebagai berikut: (a) bersifat menyerang (agresif) dan negatif, (b) dilakukan secara berulang kali, (c) adanya ketidakseimbangan kekuatan antara pihak yang terlibat. Menurutnya bahwa bullying itu terjadi ketika seseorang berusaha untuk menyakiti secara psikologis ataupun fisik terhadap seseorang atau sekelompok orang yang lebih lemah, oleh seseorang atau sekelompok orang yang lebih kuat. Perilaku bullying sebagai bentuk perlakuan yang tidak menyenangkan yang dialami oleh siswa di sekolah.

Pengertian yang dikemukakan oleh para ahli tersebut di atas, dapat disimpulkan bahwa bullying merupakan sebuah situasi dimana terjadi tindakan penyalahgunaan kekuatan atau kekuasaan yang dilakukan oleh seorang atau kelompok yang melakukan tindakan negatif karena merasa memiliki kekuasaan dan kekuatan dengan menyakiti orang lain secara fisik, verbal, dan psikologis yang dilakukan tidak hanya sekali bahkan dapat berkelanjutan sehingga dapat merugikan orang lain dan mengakibatkan seseorang dalam keadaan tidak nyaman atau terluka dan menderita, termasuk tindakan yang direncanakan maupun secara spontan, bersifat nyata atau hampir tidak terlihat dihadapan seseorang atau dibelakang seseorang, mudah untuk diidentifikasi atau terselubung dan dilakukan secara sadar dan sengaja.

Fenomena perilaku bullying dapat dianalisa dari "teori belajar sosial berdasarkan rumusan reciprocal triadic (interaksi timbal balik antara kepribadian-lingkungan- perilaku)", (Bandura, 1997: 6). Teori ini menjelaskan bahwa dari sisi internal, perilaku bullying muncul sebagai hasil keyakinan anak bahwa ia mampu mengendalikan fungsi diri mereka dan kejadian lingkungan serta kemampuan untuk mengeksplorasi, memanipulasi dan memengaruhi lingkungan demi hasil yang diinginkannya.

Bandura menggunakan istilah reciproc untuk menunjukkan interaksi triadic faktor tersebut. Ketiga faktor reciproc ini tidak perlu sama kuat atau setara. Namun, ketiganya relatif beragam tergantung pribadi dan situasinya.

Teori belajar sosial Bandura secara singkat menyatakan bahwa anak belajar dari lingkungannya sehingga kemudian diproduksi dalam dinamika pribadi dan perilaku. Teori ini melihat secara seimbang unsur internal dan eksternal anak. Faktor internal berupa kepribadian dan perilaku dipandang sebagai faktor reaksi yang dinamis dalam berkembangnya perilaku bullying. Selain itu, faktor lingkungan berupa keberadaan significant others yang dia amati dan lihat secara tidak langsung dicerna dan reproduksi perilakunya sebagai dinamika modeling dalam proses pembelajaran perilaku. Kepribadian dan perilaku individu bersama dengan faktor lingkungan saling berinteraksi dan saling memengaruhi dalam merespon situasi yang dihadapi (Feist \& Feist, 2006).

Analisa lain adalah perilaku bullying muncul sebagai respon aktif anak dalam menghadapi situasi atau reaksi lingkungan. Secara umum teori Bandura menyatakan bahwa perilaku bullying disebabkan karena adanya model perilaku dan berulang karena adanya penguat dari perilaku yang telah dilakukannya (Wenar \& Kerig, 2005).

Bentuk-bentuk bullying antara lain :

a. Bullying fisik yaitu perilaku yang dilakukan secara langsung ke korban seperti memukul, menendang, mendorong, meninju, menampar, membanting, dan merusak barang.

b. Bullying verbal yaitu tindakan yang dilakukan dalam bentuk lisan yang di tujukan kepada korban seperti celaan, fitnah, menghina, mengancam, menuduh, menyoraki, memaki, menebar gosip, dan mengejek-ejek.

c. Bullying mental/ psikologis ini sulit dideteksi dari luar. tindakan yang di lakukan oleh pelaku dengan bahasa-bahasa tubuh yang di tunjukan langsung di hadapan korban. Contohnya melihat dengan sinis, menjulurkan lidah, menampilkan ekspresi muka yang merendahkan, mengucilkan atau mengabaikan.

Bullying bisa langsung maupun tidak langsung. Bentuk-bentuk langsungnya termasuk serangan fisik atau verbal dan pengasingan relasional sosial. Sedangkan bullying tidak langsung misalnya menyebarkan rumor jahat atau merusak barang kepunyaan, termasuk yang lebih mutakhir sekarang ini adalah cyberbullying atau bullying elektronik.

Dan Olweus (1997) merumuskan karakteristik pelaku bullying sebagai berikut: (1). Kekuatan yang memaksa untuk mendominasi dan menundukkan siswa lain untuk memperoleh hal yang diinginkan, (2). Menuruti kata hati dan mudah marah, (3). Sedikit menunjukkan empati atau kepedulian terhadap siswa yang menjadi korban, (4). Seringkali menantang dan agresif terhadap orang dewasa termasuk kepada orang tua dan guru, (5). Seringkali terbawa dalam antisosial pada yang lain atau terbiasa melakukan kegiatan seperti vandalism, kenakalan dan penggunaan obat-obatan, (6). Jika mereka adalah remaja laki-laki biasanya secara fisik kuat dari pada remaja laki-laki yang lainnya dan terutama pada korban mereka.

Rigby (Astuti: 2008) yang menguraikan beberapa karakteristik pelaku bullying, diantaranya sebagai berikut: a) tidak matang secara emosional, b) tidak mampu menjalin hubungan akrab, c) kurang kepedulian terhadap orang lain, d) moody dan tidak konsisten, e) mudah marah dan impulsive, f) tidak memiliki rasa bersalah atau menyesal.

Faktor penyebab terjadinya bullying pada dasarnya dibagi menjadi dua yaitu faktor internal dan eksternal. Faktor internal adalah: (a) karakteristik kepribadian, (b) kekerasan yang dialami sebagai pengalaman masa lalu, (c) sikap keluarga yang memanjakan anak sehingga tidak membentuk kepribadian yang matang. Faktor eksternal yang menyebabkan kekerasan adalah: (a) lingkungan, dan (b) budaya. Hoover, et al., (1998). 
Menurut Purwanto (2015) bahwa perilaku bullying berdampak buruk bagi korban, saksi atau penonton maupun bagi pelakunya. Dampak buruk bagi korban tindakan bullying antara lain: kecemasan, merasa kesepian, rendah diri, depresi, dan penurunan prestasi akademik. Sementara pelaku bullying tidak akan terlepas dari resiko berikut: sering terlibat dalam perkelahian, mengalami cidera akibat perkelahian, bolos dari sekolah, dan rendahnya sikap menghormati kepada sesama teman dan guru. Sementara untuk, mereka yang menyaksikan tindakan bullying pada teman-temannya berada pada resiko menjadi penakut dan rapuh, sering mengalami kecemasan, dan rasa keamanan diri yang rendah.

Bullying umumnya mengarah pada tindakan kekerasan yang semakin besar dan berkepanjangan yang tidak hanya merugikan korbannya saja tetapi juga pada pelaku khususnya menghambat peluang untuk bisa belajar dan berprestasi di sekolah sekaligus memberi efek negatif pada iklim sekolah.

Upaya yang dapat dilakukan dalam pemberian bantuan layanan bimbingan dan konseling bagi siswa untuk mengurangi perilaku pelaku bullying di sekolah yaitu dengan pendekatan komprehensif. Perlakuan atau intervensi yang dapat diberikan oleh guru BK terhadap pelaku bullying, antara lain:

1. Memberikan layanan informasi mengenai bullying di sekolah dalam berbagai macam bentuk dan kegiatan yang dilakukan bersama dengan pihak sekolah

2. Menetapkan aturan bersama di dalam sekolah untuk mencegah berkembangnya perilaku bullying di sekolah

3. Mengajak orang tua siswa untuk ikut aktif dalam permasalahan bullying di sekolah

4. Memberikan layanan informasi kepada guru dan orang tua siswa untuk menciptakan lingkungan yang kondusif agar tidak memicu munculnya pembentukan calon-calon yang berperan dalam perilaku bullying.

Sementara upaya pencegahan untuk memutus siklus bullying menurut Townsend (1998) adalah peran serta orang tua, peran seorang konselor di institusi pendidikan dan peran lingkungan. Sikap yang bijaksana dan arif sangat diperlukan dalam menangani pelaku bullying. Upaya untuk memperkecil atau bahkan meniadakan perilaku bullying di sekolah harus terus dilakukan, termasuk mengurangi kehadiran orang-orang yang mendukung dan menumbuh suburkan perilaku pelaku tersebut. Penelitian ini menegaskan bahwa menangani pelaku bullying harus dengan sikap yang tegas tetapi bijaksana.

Penelitian awal ini diperoleh dari pengamatan terhadap sejumlah siswa di MAN 1 Barru khususnya kelas XI.MIA1. Sesuai data yang diperoleh dari buku catatan kasus BK bahwa pada hari selasa tanggal 3 Mei 2016 pelaku (ZA) telah menganggu teman sekelas dengan mengejek dan memukul sehingga menyebabkan korban bullying merasa tidak nyaman sehingga berdasarkan kajian literatur maka dibutuhkan bentuk penanganan yang lebih tepat untuk membantu siswa dalam menangani perilaku bullying.

Berdasarkan kondisi objektif tersebut, maka rumusan masalah dalam penelitian ini yaitu bagaimanakah gambaran perilaku pelaku bullying siswa MAN 1 Barru, Faktor- faktor apa saja yang menyebabkan terjadinya perilaku bullying pada siswa MAN 1 Barru, Apa saja dampak perilaku pelaku bullying pada siswa MAN 1 Barru, dan Bagaimana upaya penanganan yang telah dilakukan guru bimbingan dan konseling bagi pelaku bullying pada siswa MAN 1 Barru?

Tujuan penelitian ini adalah untuk mengetahui gambaran perilaku pelaku bullying siswa MAN 1 Barru, untuk mengetahui faktor- faktor yang menyebabkan terjadinya perilaku bullying pada siswa MAN 1 Barru, untuk mengetahui dampak perilaku pelaku bullying pada siswa MAN 1 Barru dan untuk mengetahui upaya penanganan yang telah dilakukan guru bimbingan dan konseling bagi pelaku bullying pada siswa MAN 1 Barru.

Manfaat penelitian ini terbagi dua yaitu manfaat teoritis dan praktis. Secara teoritis, penelitian ini diharapkan dapat memberikan sumbangan positif atau kontribusi secara subtantif- konseptual- teroritis untuk pengembangan keilmuan di bidang bimbingan dan konseling, khususnya untuk pelaksanaan penelitian berikutnya. Secara praktis manfaat yang diharapkan adalah hasil penelitian ini dapat menjadi masukan bagi guru pembimbing, sebagai bahan untuk mengembangkan penyusunan program bimbingan dan konseling serta peningkatan kualitas layanan bagi siswa.

\section{METODE}

Penelitian ini menggunakan pendekatan kualitatif dengan metode studi kasus Teknik pengumpulan data yang digunakan dalam penelitian ini adalah adalah wawancara mendalam (indepth interview), partisipasi observasi (participant observation), studi dokumentasi dan gabungan ketiganya atau trianggulasi. Pertanyaan yang diberikan kepada responden adalah pertanyaan-pertanyaan terbuka.

Teknik analisis data yang digunakan adalah reduksi data, display data, penarikan kesimpulan dan verifikasi. Analisis data kualitatif dilakukan pada setiap kali data dikumpulkan atau dilakukan secara bersamaan dengan proses pengumpulan data. Selanjutnya, data yang telah direduksi dibaca dengan hati-hati untuk mengenali secara cermat pola dan tema fenomena yang diteliti (Miles dan Huberman, 1994).

\section{HASIL DAN PEMBAHASAN}


Berikut ini dipaparkan hasil penelitian dari data yang diperoleh mengenai fenomena bullying di sekolah. Langkah awal studi kasus dilakukan proses identifikasi kasus yang dimana pada proses ini ditetapkan satu orang siswa yang akan menjadi subjek dalam penelitian yaitu ZA yang teridentifikasi sebagai pelaku bullying. Berikut ini dipaparkan hasil penelitian dari data yang diperoleh di lapangan tentang fenomena bullying di sekolah. Bagian pertama akan dijelaskan mengenai gambaran perilaku bullying yang meliputi bentuk - bentuk perilaku bullying dan karakteristik pelaku, faktor penyebab perilaku bullying, dan dampak perilaku bullying serta upaya penanganan yang telah dilakukan oleh guru BK. Pada bagian kedua akan dilakukan analisis pembahasan terhadap temuan lapangan yang di dapat berdasarkan dengan kerangka pemikiran yang digunakan sebagai acuan.

\section{Bentuk Perilaku Pelaku Bullying}

Perilaku ZA cenderung melakukan bullying sesuai dengan hasil wawancara dan pengamatan (observasi). Adapun bentuk perilaku bullying tersebut kepada kasus diajukan pertanyaan "Saya dengar anda pernah melakukan bullying?" ZA secara terbuka mengakui bahwa memang pernah melakukan bullying kepada temannya seperti yang dikemukakan pada saat wawancara sebagai berikut: "Saya pernah membully teman" (wwcr/ 15/11/2016/ZA).

Pernyataan tersebut diperkuat oleh penyataan NA yang telah di sampaikan pada saat wawancara ketika diajukan pertanyaan "Pernahkah di bully sama temannya?". Secara spontan responden memberi jawaban, berikut kutipan wawancaranya: "Pernah, bahkan sudah dipukul kepalaku bu" (wwcr/ 17/11/2016/NA).

Hasil wawancara dengan ZA juga mengungkapkan bahwa: "Saya marahi dan saya pukulji temanku. Seringki juga natuduh bu kalau saya yang ambil barangnya padahal bukan saya". (wwcr/ 15/11/2016/ZA)

Selanjutnya ZA juga menyebutkan secara jelas nama-nama teman yang pernah dibully sebagaimana kutipan wawancara berikut: "Yang saya bully NA, NP, NS, MT saya marahi tapi kalau SW pernah saya pukul dan saya tendang satu kali". (wwcr/ 15/11/2016/ZA)

Dari temuan di lapangan yang sudah ada, diketahui bahwa bullying yang dilakukan oleh pelaku terdiri dari bullying fisik dan verbal.

\section{Karakteristik Pelaku}

Fokus kedua dalam penelitian ini adalah mengenai karakteristik pelaku. Untuk memperoleh data mengenai karakteristik pelaku maka dilakukan observasi sebagai berikut: "Pelaku menarik barang (pulpen atau buku) temannya secara paksa". (obsr2/24/11/2016/ ZA). Untuk memperkuat data tersebut, maka berikut kutipan wawancara peneliti dengan SW yang merupakan salah seorang korban dari pelaku yang mengungkapkan bahwa: "Hubunganku baikji cuma kalau minta uang, kadang langsung diambil uang di sakuta makanya uangnya teman nasimpan atau nasembunyi di kaos kakinya". (wwcr/ 17/11/2016/SW)

Berdasarkan data di atas menunjukkan bahwa ZA memiliki karakter atau sifat yang suka memaksa dan memiliki kecenderungan untuk menguasai orang lain yang selalu ditunjukkan kepada temannya dan ZA sebagai pelaku melakukan bullying untuk meningkatkan kekuasaan, kepercayaan diri, dan popularitas dengan berdasar pada informasi yang didapatkan peneliti pada saat wawancara dengan ZA sebagai berikut: 'Supaya takutki temanku, matau' toni melle-ellekka (Supaya takut temannku dan tidak mau ejek-ejek saya lagi)". (wwcr2/06/12/2016/ZA)

Korban juga takut melawan dan tidak mau melapor kepada guru atau kepada orang tua ketika ZA melakukan agresifitas pada dirinya, dikarenakan ZA melakukan ancaman, seperti ungkapan KZ dan NR pada saat di wawancarai: “... langsung napukulki dan kalau mauki melawan bilang wuammbakotu, itani matu motoromu, naancamki juga, iya selalu ganggu cewek, ambil uang terus kalau ada tugas langsung natartek bukuta, atau marah kalau tidak di tuliskan di bukunya....". (wwcr/01/12/2016/KZ.NR)

Tidak hanya itu, ZA memiliki kebiasaan menganggu teman-temannya, yang dalam hal ini guru BK menyebutkan bahwa karakternya memang demikian karena merasa jago dengan temannya dan ZA sering juga melawan guru ketika diberi nasehat. Ketika sedang belajar, pekerjaan atau tugas temannya pun langsung diambil dan memaksa temannya untuk mengerjakan tugas sekolah atau dengan menyonteknya. SW juga mengatakan bahwa ZA sering kali memaksa temantemannya untuk mengikuti seperti apa yang diinginkannnya. ZA selalu memerintah teman-temannya termasuk dirinya ketika ZA yang bertugas membersihkan di kelas. "Kalau jadwalnya yang membersihkan kitaji yang nasuruh untuk membersihkan dia tidak mau menyapu dan membersihkan kelas". (wwcr/17/11/2016/SW). Dari hasil penelitian tersebut maka ZA sebagai subyek penelitian yang menjadi pelaku memiliki karakter yang mudah marah dan terlihat tempramental. Perilaku yang ditunjukkan pelaku sebagai bentuk pribadi yang memiliki kendali diri lemah dan memiliki pola perilaku agresif.

Perilaku yang dilakukan ZA tidak hanya dilakukan di sekolah, akan tetapi di rumah juga karena sering menunjukkan perilaku yang sama terhadap saudaranya. Hal ini seperti yang disampaikan oleh ibu pelaku saat wawancara: "Kalau di rumah sering dia memarahi adiknya, apalagi kalau barang-barangnya dipegang, biasanya marah-marah tapi tidak sampai napukul adeknya”. (wwcr/25/11/2016/SF) 
Berdasarkan klasifikasi kendali diri tersebut dengan perilaku yang ditunjukkan dalam keseharian pelaku di sekolah maka dapat dikategorikan bahwa pelaku ZA memiliki karakteristik kendali diri yang rendah atau lemah. Pelaku memiliki karakter suka memaksa dan cenderung untuk menguasai orang lain, suka memerintah, memiliki pola perilaku impulsif, agresif, memiliki kendali diri lemah karena pelaku mudah marah serta sering mengintimidasi orang lain. Oleh karena itu, kendali diri yang lemah dan buruk akan membuat pelaku menjadi memiliki banyak pikiran negatif tentang dirinya sendiri. Hal inilah yang seringkali muncul dan memicu terjadinya bullying pada pelaku.

\section{Faktor Penyebab Terjadinya Bullying}

Faktor penyebab terjadinya perilaku pada kasus ini dipengaruhi atau dilatarbelakangi oleh kondisi-kondisi yang dialami subyek, termasuk keluarga, lingkungan dan kondisi psikologis subyek. Untuk memperoleh informasi mengenai faktor penyebab terjadinya perilaku bullying, peneliti melakukan wawancara dengan subjek penelitian sekaligus wawancara dengan orang tua, teman, guru mata pelajaran dan wali kelas sebagai data informasi pendukung. Berikut kutipan hasil wawancara peneliti dengan kasus dan dengan responden lainnya.

ZA secara jujur mengungkapkan faktor penyebab melakukan perilaku bullying, seperti kutipan wawancara berikut:

"Kalau jengkelka apalagi kalau naelleka de u’tarimai, pasti macai'ikka na kkumacai'ikka wangganuini. (kalau saya jengkel karena merasa diejek saya tidak terima dan saya melampiaskan kemarahanku dengan memukul)". (wwcr02/ 06/12/2016/ZA)

Penyataan di atas, menunjukan bahwa ZA termasuk anak yang sulit mengendalikan emosi atau kendali diri sangat rendah. Situasi seperti ini menyebabkan ZA cenderung menjadi anak yang tempramental dan biasanya aktivitas-aktivitas yang dilakukan di sekolah menyebabkan dia marah dalam setiap kesempatan sehingga ZA terbiasa melakukan tindakan atau perilaku yang merugikan orang lain.

Berkaitan dengan penyebab terjadinya bullying pada pelaku, maka dari hasil wawancara dengan NA yang merupakan teman pelaku sekaligus korban mengungkapkan bahwa: “.....dia cepat naik emosinya kalau ditanya baik-baik" (wawancara /07/11/2016/NA).

Hasil temuan lapangan yang diperoleh melalui observasi bahwa faktor yang menyebabkan terjadinya bullying karena kondisi psikologis ZA ketika marah terlihat mudah tersulut emosi sehingga pelaku kurang memiliki keterampilan dalam menahan emosi dan terlihat kendali dirinya sangat lemah. Berikut hasil observasi yang telah dilakukan peneliti sebagai berikut:

"ZA tidak terima kalau dikatakan meminta uang atau memeras (memalak) temannya. Secara spontan ia memperlihatkan kemarahannya dengan menunjuk-nunjuk temannya kalau ada yang berani menuduh seperti itu, bahkan kemarahannya memuncak ketika dia meninju dinding tembok kelas dengan mata yang berkaca-kaca dengan mengeluarkan kata-kata yang menantang dan mengatakan dia tidak terima kalau dia melakukan seperti itu". (obsr03/25/11/2016/ZA)

Faktor kepribadian dan perilaku serta lingkungan individu saling berinteraksi dan saling mempengaruhi dan merespon situasi atau kondisi yang terjadi pada pelaku sebagaimana rumusan reciprocal triadic dalam teori belajar sosial Bandura. Pelaku ingin menunjukkan kekuasaan, marah karena korban tidak berperilaku sesuai dengan yang diharapkan, serta pelaku mendapatkan kepuasan apabila membully teman. Karena itu, dengan adanya perilaku agresi yang terjadi membuat pelaku merasa senang untuk menyakiti korban.

Dengan demikian, faktor penyebab perilaku bullying diantaranya kondisi psikologis pelaku yang sulit mengendalikan diri dan mudah tersulut emosi amarah, pernah mendapat perlakuan sewaktu masa kecil dari orang tuanya seperti hukuman fisik (pukulan) dan omelan. Faktor lainnya adalah adanya peluang bagi pelaku karena korban tidak pernah melapor atau bercerita kepada guru BK mengenai masalah yang dihadapi. Terakhir dikarenakan kondisi sosial pelak yaitu pelaku berasal dari keluarga miskin dan harus bekerja untuk memenuhi segala kebutuhannya sehingga cenderung melakukan perilaku bullying seperti memalak teman sekelasnya.

\section{Dampak Perilaku Bullying}

Hal yang menjadi fokus penelitian terhadap subyek yang berperilaku bullying adalah dampak yang ditimbulkan dan dialami pelaku khususnya terhadap hubungannya dengan teman sebaya termasuk pola interaksinya. Untuk memperoleh gambaran secara jelas berikut adalah hasil pengamatan dan ungkapan-ungkapan pelaku dalam wawancara sebagai berkut:

Informasi yang paling awal diperoleh peneliti sehubungan dengan dampak yang ditimbulkan perilaku bullying yang dilakukan oleh ZA adalah seperti yang diungkapkan oleh SF (ibu ZA) kepada peneliti bahwa:

"Waktunya SMP selaluka dipanggil ke sekolahnya, ada itu suratnya gurunya kalau ada lagi naganggu atau ada lagi masalahnya di sekolah". (wwcr/ 26/11/2016/SF)

Hal ini diakui oleh ZA bahwa ia pernah melakukan hal tersebut. Saat ditanya mengenai hal tersebut memang merupakan perilaku bullying yang pernah tercatat oleh guru BK. Saat di tanya mengenai perilaku tersebut ZA menceritakan kronologisnya. 
Hasil penelitian juga menunjukkan bahwa pelaku mengalami hubungan yang kurang harmonis dengan teman sekelasnya. Penyebab dari keadaan tersebut adalah ZA menunjukkan perilaku bullying baik secara verbal, dan secara fisik. Oleh karena itu, teman-teman sekelas menjauhi pelaku bahkan meminta untuk dipindahkan kelasnya. Meskipun begitu, sebenarnya sikap ZA sendiri kepada teman-teman yang sering menindas dan mengganggu membuat dirinya dijauhi oleh teman-temannya. Berbagai macam bentuk perilaku yang ditunjukkan oleh pelaku tentu akan berdampak secara sosial baik di lingkungan sekolah maupun di rumah.

\section{Upaya Penanganan Perilaku Bullying yang Telah Dilakukan Guru BK}

Perilaku bullying yang dilakukan pelaku dapat ditangani dengan menggunakan pendekatan-pendekatan dalam bimbingan dan konseling, seperti hasil wawancara peneliti dengan guru BK, sebagaimana kutipan wawancara berikut:

"Ketika ada laporan dari siswa kalau ZA mengganggu temannya, saya panggil ke ruang BK. Saya kasi teguran dengan membuat pernyataan di dalam buku kasus dan juga diberi sanksi sesuai pelanggarannya. Sanksinya seperti menyapu, membersihkan mushallah". (wwcr/ 26/11/2016/NJ)

Sementara Guru BK yang lain mengatakan bahwa apabila ZA membully temannya maka dipanggil untuk di konseling, atau diberikan surat pemberitahuan kepada orang tuanya sebagai bentuk kerjasama dengan orang tua siswa.

"Kalau dilihat dari tingkat pelanggaran dan jenis pelanggaran yang dilakukan maka terlebih dahulu saya panggil untuk dikonseling, dinasehati. Namun jika pelaku mengulangi perbuatannya seperti memukul temannya, saya kasi pemberitahuan kepada orang tuanya".(wwcr/ 05/12/2016/AU)

Adapun bentuk penanganan melalui bimbingan dan konseling individu menurut guru BK yakni dilakukan dengan memanggil pelaku ke ruang BK, kemudian pelaku di ajak ngobrol dan di beri nasehat supaya tidak melakukan hal yang sama lagi dengan temannya. Adapun bentuk kolaborasi dengan wali kelas yaitu dengan adanya kerjasama antar guru BK dan wali kelas dengan menyampaikan atau mengkonsultasikan bahwa ada permasalahan dengan siswanya sehingga samasama memberikan perhatian dan penanganan.

Peneliti menawarkan beberapa hal yang terkait dengan intervensi sekolah untuk menghentikan dan mencegah perilaku bullying, sebagai berikut:

1. Melalui pendekatan kedisiplinan; dengan menyadarkan kepada seluruh warga sekolah bahwa bullying dalam bentuk apapun tidak dapat ditolelir.

2. Melakukan penguatan pada korban bullying dengan melatih dengan keassertifan siswa

3. Melakukan mediasi antara pelaku dan korban dengan memberikan pengertian bahwa rasa aman dan nyaman adalah hak dan milik seluruh siswa.

4. Melaksanakan atau mengadakan kegiatan rekresasi bersama; misalnya ikut dalam kegiatan outbound atau kegiatan lainnya dengan melatih kerjasama dan tanggung jawab siswa.

5. Melakukan atau mendorong aktivitas bimbingan kelompok; dengan membuat gambar/poster tentang pencegahan bullying atau stop bullying.

6. Memberikan cara untuk berbagi keprihatinan dan meningkatkan empati; dengan membaca buku cerita tentang bullying, brainstorming dan diskusi, serta bermain drama/peran.

\section{KESIMPULAN}

Kesimpulan dari penelitian ini adalah sebagai berikut:

1. Gambaran perilaku bullying siswa MAN 1 Barru yakni pada kasus ZA yaitu pada bentuk dan karakteristik pelaku. Adapun bentuk perilaku pelaku bullying fisik pada kasus ZA lebih cenderung menunjukkan perilaku memukul,menampar,menendang, mendorong, meninju, memalak, serta memeluk. Sedangkan bentuk perilaku bullying verbal seperti mengejek, menghina, memanggil dengan sebutan yang buruk. Selanjutnya, karakteristik perilaku bullying pada kasus ZA sebagai reaksi dari kesulitan untuk mengendalikan emosi atau kendali diri pelaku sangat lemah.

2. Faktor penyebab perilaku bullying adalah pengalaman masa kecil yang terkait dengan pola pengasuhan yang dilakukan oleh orang tua ZA dan faktor kepribadian pelaku juga menjadi penyebab terjadinya bullying meliputi: sulit mengendalikan emosi dan cenderung tempramental disaat gagal mendapatkan atau memperoleh sesuatu yang diinginkan.

3. Dampak perilaku bullying yang dilakukan oleh pelaku sangat mempengaruhi interaksi sosial dengan temantemannya di sekolah termasuk dijauhi oleh teman-teman sekelasnya.

4. Upaya penanganan yang telah dilakukan oleh guru BK seperti: bimbingan individu yang cenderung lebih banyak teknik konseling pemberian nasehat pada pelaku, dan diperlukan upaya-upaya dan teknik lain untuk meminimalisir perilaku bullying yang terjadi disekolah seperti pelaksanaan bimbingan kelompok, konseling kelompok, layanan klasikal dengan latihan assertif dengan teknik sosiodrama, diskusi, dan lainnya. 


\section{DAFTAR PUSTAKA}

Astuti, R. 2008. Meredam Bullying: 3 Cara Efektif Menanggulangi Kekerasan Pada Anak. Jakarta: PT. Gramedia Widiasarana Indonesia.

Bandura, A. 1986. Social Foundation of Thought and Action, A Social Cognitive Theory. New Jersey: Prentice Hall

Bandura, A. 1997. Self-Efficacy: The Exercise of Control. United State of America: W.H.Freeman and Company

Coloroso, B. 2003. The Bully. The Bullied, and The Bystander: Fom Preschool To High School- How Parents and Teachers Can Help Break The Cycle of Violence. New York: Harper Resource

Corey, G. 2005. Theory and Practice of Counseling and Psychoteraphy, Terj. E.Koswara. 2013, Bandung: Refika Aditama

Craig, W.M. \& Atlas, R. 2000. Observation of Bullying in the Playgroup and in the Classroom. Journal of Publich Health, $21(1)$.

Efrord, B.T. 2015. 40 Techniques Every Counselor Should Know, Ed.2, Terj. Helly Prajitno Soetjipto. 2016, Yogyakarta: Pustaka Pelajar

Feist, J. \& Feist, G.J. 2006. Theories of Personality, Terj. Yudi Santoso. 2008, Yogyakarta: Pustaka Pelajar

Hawkins, D. L., Pepler, D., \& Craig, W. M. (2001). Peer Interventions in Play-Ground Bullying. Social Development, $10,512-527$

Hoover, J., \& Milner C.W. 1998. Are hazing and Bullying Related to Love and Belongingness? Reclaiming Children and Youth. Request Psychology Journal, 7 (3), 138-141.

Krahel, B. 2005. Perilaku Bullying-Buku Panduan Psikologi Sosial. Yogyakarta

Miles, M.B. \& Huberman, A.M. 1994. Qualitative Data Analysis A Methods Sourcebook, Ed.3. Washington DC: Sage

Mujiati, 2015. Peningkatan Self Esteem Siswa Korban Bullying melalui Teknik Assertive Learning. Jurnal Fokus Konseling, (Online), 1 (1). Diperoleh dari http://ejournal.stkipmpringsewu-lpg.ac.id/index.php/fokus

Musfiqun, M. 2012. Panduan Lengkap Metodologi Penelitian Pendidikan. Jakarta: Prestasi Pustakaraya.

Olweus, D. 1993. Bullying At School: What We Know and What We Can Do. Oxford: Blackwell

Olweus, D. 1997. Bully/Victim Problems in School: Facts dan Intervention. European Journal of Psychology of Education (12), 495-510.

Olweus, D. 2004. Bullying At School: Prevalence Estimation, A Useful Evaluation Design, and A New National Initiative In Norway. Assosiation for Child Psychology and Psychiatry Occasional Papers (23), 5-17

Priyatna, A. 2012. Intelligent Never Look So Good. Jakarta: Elex Media Komputindo

Purwanto, M.H. 2015. Hubungan Pola Asuh Orang Tua dan Hasil Belajar Mata Pelajaran Akhlak dengan Perlaku Bullying di SD Muhammadiyah Miliran Yogyakarta. (Skripsi Tidak diterbitkan). Universitas Islam Negeri Sunan Kalijaga, Yogyakarta, Indonesia.

Rigby, K. 2002. New Perspectives on Bullying. London : Jessica Kingsley.

Sugiyono. 2015. Metode Penelitian Pendidikan. Bandung: Alfabeta

Susanti, I. 2006. Bullying Bikin Anak Depresi dan Bunuh Diri. (online). Diperoleh dari http://www.psychologymania.com/2012/06/definisibullying. html

Tohirin. 2013. Metode Penelitian Kualitatif dalam Pendidikan dan Bimbingan Konseling. Jakarta: Rajawali Pers

Townsend, Flisher, A.J., Chikobvu, P., Lombard,C., \& King,G. 2008. The relationship between bullying behaviours and high school dropout in Cape TownSouth Africa. South African Journal of Psychology, 38 (1), 21-32.

Tim Buku Pintar. 2011. Undang - Undang Dasar Republik Indonesia Tahun 1945 dan Perubahannya. Jakarta: Buku Pintar

Undang-Undang No.20 Tahun 2003. Tentang Sistem Pendidkan Nasional dan Landasannya. Jakarta: Depdiknas

Undang-Undang No.23 Tahun 2002. Tentang Pelindungan Anak. Jakarta: Visimedia

Wenar, C., \& Kerig, P. 2005. Development Psychopathology from Infancy Through Adolescent, (10th Edition ed.),. New York: Mc Graw-Hill Companies Inc

Winkel, W.S. dan Hastuti, M.M. 2004. Bimbingan dan Konseling di Institusi Pendidikan. Yogyakarta: Media Abad Wiyani, A.N. 2012. Save our Children from School Bullying. Yogyakarta: Ar-Ruzz Media.

Yayasan, S.J.A. (SEJIWA). 2008. Bullying Mengatasi Kekerasan di Sekolah dan Lingkungan Sekitar Anak. Jakarta: Grasindo. 